\title{
PENGEMBANGAN MODEL INSTRUMEN PENGUKURAN CUSTOMER INTERFACE 8C
}

\author{
Fenni Supriadi ${ }^{1}$, Ryani Yulian ${ }^{2}$ \\ Prodi Manajemen Fakultas Ekonomi dan Bisnis \\ Universitas Muhammadiyah Pontianak Jl. Ahmad Yani No. 111 Pontianak
}

\begin{abstract}
This study aims to develop a measurement model of customer interface or display interface using $8 \mathrm{C}$ that is context, content, community, customization, communication, connection, commerce and collaboration on the website or website of e-commerce digital industry in West Kalimantan especially from visitor perspective. The customer interface measurement model will be developed to overcome the limitations of the commonly used model of webqual. Appropriate measurement models will greatly assist in improving the look of the website interface with the e-commerce platform. Literature studies and interviews will be used to construct measurement models. Studies are conducted on literature on web quality measurement models, e-business and e-commerce concepts, and customer interface factors in e-commerce web. Interviews were conducted on ecommerce web users. Respondents were chosen by using purposive sampling technique.

The result of the research is a measurement model of e-commerce web quality using customer interface factors as dimensions. The attributes identified for measuring the quality of e-commerce web are 16 items grouped into 8 (eight) customer interface dimensions. The development of e-commerce website measurement model is constructed into the website www.cicommerce.id comprehensively and commercially to map the position of e-commerce web customer interface.
\end{abstract}

\begin{abstract}
ABSTRAK
Penelitian ini bertujuan untuk mengembangkan model pengukuran customer interface atau tampilan antar muka menggunakan 8C yaitu context, content, community, customization, communication, connection, commerce dan collaboration pada website atau situs e-commerce industry digital yang ada di Kalbar khususnya dari persepektif pengunjung. Model pengukuran customer interface akan dikembangkan untuk mengatasi keterbatasan-keterbatasan dari model yang umum digunakan yaitu webqual. Model pengukuran yang sesuai akan sangat membantu dalam meningkatkan tampilan antar muka website dengan platform ecommerce. Studi literatur dan wawancara akan digunakan untuk membangun model pengukuran. Studi dilakukan pada literatur-literatur mengenai model pengukuran kualitas web, konsep e-business dan $e$ commerce, serta faktor-faktor customer interface dalam web e-commerce. Wawancara dilakukan terhadap pengguna web e-commerce. Responden dipilih dengan menggunakan teknik purposive sampling.

Hasil penelitian adalah sebuah model pengukuran kualitas web e-commerce yang menggunakan faktorfaktor customer interface (tampilan antar muka) sebagai dimensi-dimensinya. Atribut-atribut yang teridentifikasi untuk pengukuran kualitas web e-commerce berjumlah 16 item yang dikelompokkan ke dalam 8 (delapan) dimensi customer interface. Pengembangan model pengukuran website e-commerce dikonstruksi ke dalam website www.cicommerce.id secara komprehensif dan komersial untuk memetakan posisi customer interface web e-commerce.
\end{abstract}
Kata kunci
: Model Pengukuran, E-Commerce, Customer Interface
Korespondensi
: fennisupriadi@unmpuhpnk.ac.id 


\section{PENDAHULUAN / INTRODUCTION}

Perkembangan era teknologi informasi yang semakin pesat memberikan kemudahan transaksi tanpa batas waktu dan wilayah. Dalam kegiatan e-business ini bisa menjadi suatu tantangan sekaligus peluang untuk menciptakan segmentasi pasar yang lebih luas. Saat ini toko yang sebelumnya offline juga mencoba menyediakan fasilitas toko online yang bisa diakses di dalam suatu website secara real time dengan berbagai fitur yang memberikan pengalaman yang berbeda ketika berbelanja.

Dunia maya terbentuk seiring dengan berkembangnya pengguna internet yang terus bertambah diiringi dengan maraknya penjual online dikarenakan murah dan mudahnya membuat sebuah website online yang bisa dilakukan dimanapun, namun memiliki akses secara global oleh para pengguna internet di dunia. Hal ini menjadi pasar potensial bagi para pebisnis yang mencoba mengintegrasikan bisnis offlinenya dengan membangun website/toko secara online. Perusahaan atau pemilik dapat lebih mendekatkan diri dengan konsumen dimana jarak secara fisik dapat diatasi. Berikut adalah data pengguna internet di dunia.

Tabel 1

Data Pengguna Internet di Dunia

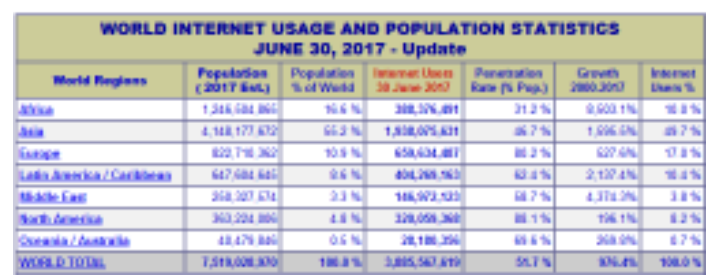

Sumber : www.internetworldstats.com

Jumlah pengguna internet yang

paling dominan di Asia menjadi sasaran bagi banyak negara dalam upaya meningkatkan penjualan onlinenya. Di negara Indonesia sendiri pengguna internet mengalami peningkatan jumlah dari tahun ke tahunnya.
Data dari www.internetworldstats.com tahun 2017 menunjukkan bahawa jumlah pengguna internet di Indonesia sebanyak 132.700.000 dari 263.510.146 populasinya dengan penetrasi sebesar 50,4\%.

Meningkatnya jumlah pengguna internet sendiri telah menarik berbagai macam dan sektor bisnis untuk mempromosikan produknya di dunia maya melalui jaringan internet dan sekaligus untuk melakukan transaksi perdagangan dari fitur yang disediakan website e-commerce online. Pelaku usaha industri digital yang telah dan mulai mencoba menerapkan e-commerce (perdagangan elektronik) perlu membangun customer interface yang baik sehingga membuat konsumen (pengunjung) betah dan melakukan pembelian (transaksi) secara online serta pada gilirannya menjadi konsumen loyal (repeat, retention \& referral).

Dengan potensi pengguna internet lebih dari 100 juta, 1.000 technopreneur dan 70 juta pengguna telepon pintar (smartphone) memberikan peluang bagi digital economy Indonesia untuk menjadi Raksasa ECommerce ASEAN 2025. Untuk itu, diperlukan pengembangan model instrumen pengukuran kualitas web e-commerce dengan melibatkan customer interface yang bisa memetakan kondisi tampilan antar muka yang dimiliki perusahaan e-commerce untuk meningkatkan performa, fitur dan layanannya dalam upaya menarik investor dan visitor (user) serta peningkatan transaksi bisnis $e$ commerce.

\section{DASAR TEORI \\ E-Business dan E-Commerce}

Istilah e-business dan e-commerce sering terlihat dan digunakan untuk proses yang sama. Namun demikian, meskipun berhubungan, keduanya memiliki arti yang berbeda. Awalan "e" berarti "elektronik", 
yang berarti kegiatan atau transaksi yang digunakan tanpa pertukaran atau kontak fisik. Transaksi diadakan secara elektronik atau digital, sesuatu dibuat menjadi mungkin dengan pesatnya perkembangan komunikasi digital.

E-Business adalah praktek pelaksanaan dan pengelolaan proses bisnis utama seperti perancangan produk, pengelolaan pasokan bahan baku, manufaktur, penjualan, pemenuhan pesanan, dan penyediaan servis melalui penggunaan teknologi komunikasi, komputer, dan data yang telah terkomputerisasi (Alter, 2002).

Sedangkan e-commerce merupakan kepanjangan dari Electronic Commerce yang berarti perdagangan yang dilakukan secara elektronik. Dalam buku Introduction to Information Technology, ecommerce berarti perdagangan elektronik yang mencakup proses pembelian, penjualan, transfer, atau pertukaran produk, layanan, atau informasi melalui jaringan computer, termasuk internet (Turban, 2005:181).

\section{CUSTOMER INTERFACE}

Menurut Mohammed et. al. (2004: 161) Customer interface adalah representasi dari proposisi nilai suatu perusahaan. Mirip dengan toko ritel, interface pada website memberikan informasi penting kepada pelanggan dan target pasar. Jika dapat didesain dengan efektif, maka konsumen akan merasa situs tersebut layak untuk dikunjungi dan menjawab kebutuhan dasar dari konsumen. Website/toko online yang menarik dapat memvisualisasikan dan mengkomunikasikan nilai inti dari proporsi perusahaan dan memberikan alasan untuk mengunjungi bahkan menjadi pelanggan dari website/toko online tersebut.

$7 C$

Customer interface yang efektif adalah yang dapat menampilkan tujuh elemen desain yang disebut $7 \mathrm{C}$, yaitu context, content, community, customization, communication, connection, dan commerce (Kotler dan Keller, 2012: 563). Context adalah tampilan dan nuansa yang disajikan kepada para konsumen. Content yang dimaksud adalah termasuk audio, video, gambar dan teks. Community adalah jalinan hubungan yang dibangun untuk kepentingan bersama. Customization adalah 'Kemampuan situs untuk menghantarkan dirinya pada berbagai pengguna atau memungkinkan pengguna mempersonalisasikan situs. Communication dapat dilakukan melalui sign up untuk penawaran khusus, e-mail berlangganan, kontes, survei, live chat dengan admin yang telah ditunjuk, ataupun informasi kontak perusahaan. Connection adalah bagaimana sebuah situs terhubung dengan situs lain melalui hypertext atau hyperlink, dari satu website ke website lainnya. Commerce adalah 'Kemampuan situs untuk memungkinkan transaksi komersial.

$8 C$

Penilaian kinerja customer interface lebih banyak menggunakan 7C sebagaimana referensi dari Rayport dan Jaworski, namun Yang. et al. (2008) menambahkan dari 7C menjadi 8C dan menciptakan referensi baru dengan collaboration sebagai unsur $\mathrm{C}$ ke delapan. Menurut Yang et. al. (2008), menyatakan bahwa collaboration merupakan kemampuan situs untuk memungkinkan konsumen melakukan kolaborasi seperti memberikan saran dan komentar untuk manajemen proyek, kerja sama dan lain sebagainya.

Hansen dan Andersen (2013)

pada Cube Assessment Framework for B2C Websites Applied in a Longitudinal Study in The Luxury Fashion Industry, menyatakan bahwa collaboration dapat didefinisikan sebagai keterlibatan konsumen dalam merancang dan mengembangkan produk, termasuk memberikan saran dan komentar 
mengenai merek lain yang terkait.

\section{METODE PENELITIAN / METHODS}

Untuk menyelesaikan permasalahan yang dihadapi dalam merancang model instrumen pengukuran tampilan antarmuka website e-commerce dengan menggunakan customer interface 8C (context, content, community, customization, communication, connection, commerce dan collaboration), maka metode penelitian yang digunakan adalah pengembangan sistem informasi dengan model spiral dengan tahapantahapan sebagai berikut:

1. Komunikasi pelanggan; Komunikasi antar pengembang dan user secara efektif dalam hal ini pelanggan atau pengujung situs (visitor).

2. Perencanaan; Mendefinisikan sumber daya, batas waktu dan sumber lainnya

3. Analisis Resiko; Menentukan resiko teknis dan manajemen

4. Perekayasaan; Membuat satu atau lebih aplikasi yang dapat diwakili

5. Konstruksi dan Peluncuran; Mengkonstruksi, menguji, menginstall dan memberikan pendukung user (dokomen dan training)

6. Evaluasi Pelanggan; Melakukan evaluasi dan penilaian terhadap umpan balik "feed back" pelanggan.

Model pengukuran yang telah dirancang akan diberikan skala pengukuran, bobot dan kriteria penilaian kemudian diimplementasikan untuk mengukur customer interface web e-commerce. Populasi yang digunakan dalam penelitian ini adalah pelanggan yang tergabung dan telah menjadi anggota (member) di group facebook/fanspage pada 5 (lima) Toko Komputer wilayah Pontianak Kalimantan Barat. Sedangkan sampel dalam penelitian ini berjumlah 100 orang responden yang diambil masing-masing 20 responden dari setiap toko komputer dengan proporsi sebagai berikut:

1. Datacom

Digital (www.datacomdigital.com) sebanyak 20 orang.

2. Database Computer (www.database.id) sebanyak 20 orang.

3. Grace Computer (www.gracekomputer-ptk.com) sebanyak 20 orang.

4. Menara Computer (www.menaracomputer.com) sebanyak 20 orang.
5. Jayaputra Computer (www.jayacomputer.co.id) sebanyak 20 orang.

\section{HASIL DAN PEMBAHASAN}

Model dasar yang digunakan dalam pengukuran konstruk kualitas website ecommerce memiliki dimensi-dimensi yang diadaptasi dari 8 (delapan) faktor customer interface industri digital. Berdasarkan penggunaan teori customer interface dalam mengukur kualitas tampilan antar muka website e-commerce, dapat didefinisikan kualitas website e-commerce sebagai penilaian kinerja/persepsi konsumen terhadap tampilan antar muka website e-commerce ditinjau dari 8 (delapan) dimensi yaitu context, content, community, customization, communication, connection, commerce dan collaboration. Keterkaitan konstruk kualitas website e-commerce dan 8 (delapan) dimensi dapat dipahami melalui deskripsi berikut yaitu ketika konsumen diminta untuk menjelaskan mengapa website e-commerce yang digunakannya dianggap berkualitas, maka konsumen diperkirakan akan memberikan alasan-alasan yang berkaitan dengan fitur-fitur layanan layanan, fasilitas yang disediakan, proses transaksi yang mudah dan aman, customer support yang berkompeten dan lain-lain. Model pengukuran kualitas website e-commerce ditunjukan oleh gambar 1 berikut: 
Balance Vol. XV No. 1 | Januari 2018

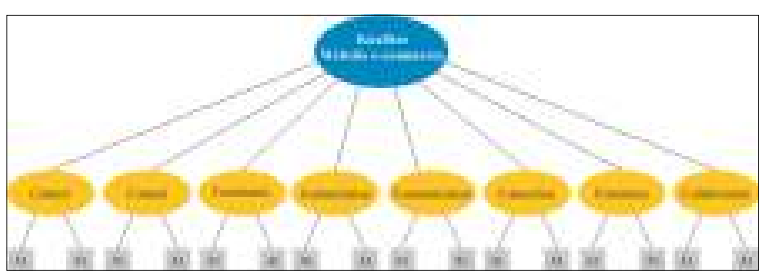

Gambar 1 Model Pengukuran Customer Interface

Atribut pengukuran kualitas website ecommerce dengan customer interface 8C berjumlah 16 item. Atribut penilaian dan bobot pengukuran menggunakan customer interface disajikan pada tabel 2 berikut ini:

Tabel 2

Atribut dan Bobot Customer Interface

\begin{tabular}{|c|l|c|c|}
\hline No & \multicolumn{1}{|c|}{ Customer Interface } & $\begin{array}{c}\text { Skala } \\
\text { Pengukuran }\end{array}$ & $\begin{array}{c}\text { Bobot } \\
(\%)\end{array}$ \\
\hline 1. & Design dan Layout & $1-4$ (Likert) & $7 \%$ \\
\hline 2. & Slide & $1-4$ (Likert) & $4 \%$ \\
\hline 3. & Text dan Picture & $1-4$ (Likert) & $6 \%$ \\
\hline 4. & Animasi dan Video & $1-4$ (Likert) & $4 \%$ \\
\hline 5. & Sharing Sosmed & $1-4$ (Likert) & $6 \%$ \\
\hline 6. & Membership Fitur & $1-4$ (Likert) & $4 \%$ \\
\hline 7. & Personalisasi Account & $1-4$ (Likert) & $3 \%$ \\
\hline 8 & Update Fitur Account & $1-4$ (Likert) & $2 \%$ \\
\hline 9. & Konfirmasi pembelian dan CSO & $1-4$ (Likert) & $10 \%$ \\
\hline 10. & Purna Jual & $1-4$ (Likert) & $10 \%$ \\
\hline 11. & Akses Situs Utama & $1-4$ (Likert) & $8 \%$ \\
\hline 12. & Akses Link Menu Layanan & $1-4$ (Likert) & $7 \%$ \\
\hline 13. & Aplikasi Shopping/Belanja & $1-4$ (Likert) & $10 \%$ \\
\hline 14. & Fitur Keamanan Berbelanja & $1-4$ (Likert) & $10 \%$ \\
\hline 15. & Keterlibatan Konsumen & $1-4$ (Likert) & $4 \%$ \\
& Merancang Produk & & \\
\hline 16. & Saran dan Komentar & $1-4$ (Likert) & $5 \%$ \\
\hline
\end{tabular}

Untuk mengetahui implementasi customer interface 8C digunakan analisis deskriptif dengan pembuatan kuesioner online yang dibuat dengan google form untuk mendapatkan gambaran data yang diperoleh dari jawaban untuk setiap item/butir pernyataan. Berdasarkan jawaban tersebut, kemudian disusun kriteria penilaian untuk setiap item pernyataan. Skala penilaian menggunakan skala likert seperti table 3 berikut ini:

Tabel 3

Kriteria Penilaian Customer Interface

\begin{tabular}{|l|l|c|c|}
\hline No & Kriteria Penilaian & Persentase (\%) & Skor \\
\hline 1. & Sangat Baik & $81,25-100$ & 4 \\
\hline
\end{tabular}

\begin{tabular}{|l|l|c|c|} 
2. & Baik & $62,5-81,25$ & 3 \\
\hline 3. & Buruk & $43,75-62,5$ & 2 \\
\hline 4. & Sangat Buruk & $25-43,75$ & 1 \\
\hline
\end{tabular}

Nilai kumulatif adalah jumlah nilai dari setiap item pernyataan yang merupakan jawaban dari 100 responden. Persentase adalah nilai kumulatif item dibagi dengan nilai frekuensi dikalikan $100 \%$. Jumlah responden adalah 100 dan nilai skala pengukuran terbesar adalah 4, sedangkan skala pengukuran terkecil adalah 1 . Sehingga diperoleh jumlah kumulatif terbesar $=100 \times 4$ $=400$ dan jumlah kumulatif terkecil adalah $100 \times 1=100$. Nilai persentase terkecil = $(100 / 400) \times 100 \%=25 \%$. Nilai Rentang $100 \%-25 \%=75 \%$ dan jika dibagi 4 (skala pengukuran) maka didapat nilai interval persentase sebesar 18,75\%. Kategori dan interprestasi penilaian customer interface dapat dijelaskan pada gambar 2 berikut ini:

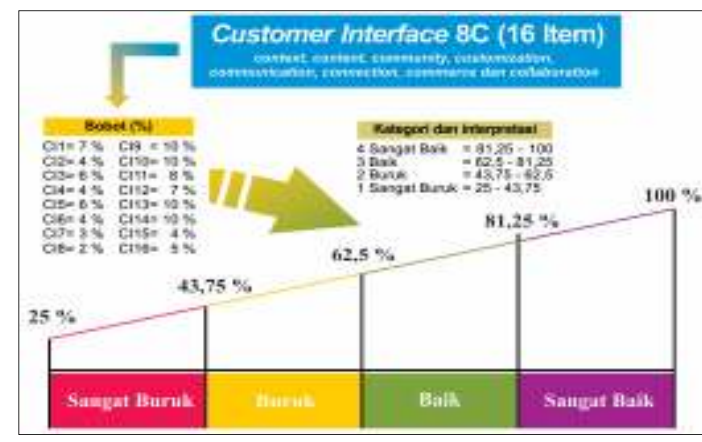

Gambar 2 Kriteria Penilaian Customer Interface

\section{KESIMPULAN}

Dari hasil pengembangan pengukuran customer interface 8C (content, context, community, communication, customization, connection, commerce dan collaboration) terbentuklah model awal pengukuran customer interface web perusahaan digital yang menerapkan e-commerce (perdagangan elektronik) dalam transaksi bisnisnya secara online. Untuk membantu para pelaku usaha dunia online, model pengukuran customer interface 8C telah dikonstruksikan ke cloud system yang bisa diakses perusahaan digital/UKM yang ingin mengetahui 
posisi/nilai customer interface web perusahaan dengan mengunjungi www.cicommerce.id.

Implementasi pengukuran yang dilakukan pada 5 (lima) web toko komputer yang ada di kota Pontianak dapat disimpulkan bahwa customer interface yang dimiliki berada pada kategori baik secara berurutan mulai dari Database Komputer (www.database.id) nilai 76,6\%, Datacom Digital (www.datacomdigital.com) dengan nilai $74,95 \%$, Grace Komputer (www.gracekomputer-ptk.com) dengan nilai 70,95\%, Menara Komputer (www.menarakomputer.com) dengan nilai $70,90 \%$ dan Putrajaya Komputer (www.jayacomputer.co.id) dengan nilai 67\%.

Berdasarkan penilaian customer interface, masing-masing perusahaan memiliki kekuatan dan kelemahan pada fiturfitur yang disediakan. Database Komputer memiliki tampilan antar muka yang memiliki kekuatan fitur yang baik pada customization. Disisi lain, Datacom Digital memiliki fitur yang baik pada connection. Sementara, Grace Komputer memiliki fitur yang baik pada communication. Sedangkan, Menara Komputer memiliki fitur yang baik pada context.

\section{SARAN}

Model awal yang dihasilkan dari penelitian awal dapat digunakan dalam penelitian selanjutnya untuk mengetahui hubungan customer interface dengan loyalitas di indsutri digital. Customer interface salah satu item yang bisa menjadi instrumen pengukuran yang dapat digunakan oleh perusahaan online untuk melihat secara komprehensif posisi tampilan antar muka website e-commerce perusahaan saat ini dimana perusahaan harus meningkatkan/memperbaiki item pengukuran yang dianggap masih memiliki kelemahan atau kekurangan (kategori buruk) serta mempertahankan atau meningkatkan item pengukuran yang dianggap sudah baik.

Diharapkan kedepan, model pengukuran customer interface tidak hanya bisa digunakan untuk mengukur web komersil (Skala menengah ke atas) tetapi juga dikembangkan model pengukuran web untuk UKM (Usaha Kecil Mikro) dan Instansi atau Organisasi non profit yang orientasinya pada peningkatan kualitas layanan publik.

\section{DAFTAR PUSTAKA}

Alfian, Paulus Sukapto dan CarlesSitompul. 2011. Pengembangan Model Pengukuran Kualitas Lyanan e-Banking Dengan Melibatkan Faktor-Faktor Bauran Pemasaran. Prosiding Seminar Nasional dan Workshop Pemodelan dan Perancangan Sistem. Universitas Katolik Parahiyangan.

Chasanah, Umi. 2010. Pengembangan Instrumen Penilaian Domain Afektif Pada Mata Pelajaran PKn Di Sekolah Menengah Pertama. Jurnal Forum Sosial Vol. V, No. 02. Universitas Sriwijaya.

Hansen, R. dan N. Bjorn-Andersen (2013). Cube Assessment Framework for B2C Websites Applied in a Longitudinal Study in the Luxury Fashion Industry. Journal of Theoretical and Applied Electronic Commerce Research. Vol 8, hal 17-18, Chile.

Hamidizadeh, Mohammad R., Mohammad E. Fadaeinejad dan Fayegh Mojarrad (2011). Design of Internet Marketing Based on 7Cs Model. International Conference on Social Science and Humanity IPEDR. Vol. 5, hal 276-280, Singapore.

Kementerian Komunikasi dan Informatika Republik Indonesia. Kemkominfo: Pengguna Internet di Indonesia Capai 82 Juta. Diakses 22 Januari 2016, dari http://kominfo.go.id

Kotler, P. dan K. L. Keller (2012). Marketing Management. Fourteenth Edition, London. Pearson Education Limited.

Laudon K. C. dan C. G. Traver (2012). Ecommerce 2012. Eighth Edition, New Jersey, Pearson Prentice Hall/Education.

Mohammed, R., R. J. Fisher, B. J. Jaworski dan G. Paddison (2004). Internet Marketing: Building Advantage in a Networked Economy 2003. International edition, New York, McGraw-Hill/Irwin.

Qomari, Rohmat. 2008. Pengembangan 
Instrumen Evaluasi Domain Afektif. Jurnal Pemikiran Alternatif Pendidikan;

13(1):87-109. Purwokerto: STAIN Purwokerto.

Rayport, J. F. dan B. J. Jaworski (2005). Introduction to E-Commerce. New York, McGraw-Hill/Irwin.

Yang, T. A., D. J. Kim, V. Dhalwani dan Tri K. $\mathrm{Vu}$ (2008). The 8C Framework as a reference Model for Collaborative Value Webs in the Context of Web 2.0. Vol 41, hal 7, Texas.

Zikmund, W. G. \& B. J. Babin (2013). Essentials of Marketing Research. Fifth Intenational Edition, South-Western, Cengage Learning. 